\title{
OVERALl INJUSTICE, WORKPLACE Deviance AND Turnover INTENTION Among Educators and Supporters
}

Syed Tahir Rizvi, Barry A. Friedman, and Rauf I. Azam

Syed Tahir Rizvi (proffsyed@gmail.com) is a PhD Scholar Capital at University of Science and Technology Islamabad and Coordinator Higher Studies and Research at International Islamic University, Islamabad, Barry A. Friedman (barry.friedman@oswego.edu) is Professor of Organizational Behavior and Human Resource Management at the State University New York at Oswego and Suleyman Sah University, 247 Rich Hall, State University of New York at Oswego, Oswego, New York 13126 USA. Rauf I. Azam (rauf.i.azam@gmail.com) is Vice Chancellor University of Education Lahore. Correspondence regarding this paper should be addressed to Syed Tahir Rizvi.

\begin{abstract}
Organizations strive for environments where employees effectively interact. Innovative approaches are, therefore, necessary for organizational sustainable growth, development and survival. Fundamental to human social interaction is fairness and justice. Fairness and justice has to be addressed in such organizational decisions as promotion, task assignment, reward distribution and
\end{abstract}


other social exchanges (Coetzee, 2004). Employees' perception of organizational justice affects their behavior performance and organizational success. This paper reports a field study based on the survey method targeting higher education institutional employees. The research objective is to highlight the relationship between overall injustice and unfairness perception in the organizational climate and negatively-oriented employees' behaviors (e.g., workplace deviance and turnover intention). The perception of overall organizational injustice was positively correlated to workplace deviance and turnover intention. However, the correlation between overall organizational injustice and turnover intention among educators was higher than that of the staff supporters. In addition, the correlation between overall organizational injustice and workplace deviance for staff supporters was higher than that of the educators. Implications are discussed.

Keywords: Overall organizational injustice, workplace deviance, turnover intention

DOI: http://dx.doi.org/10.15239/j.brcacadjb.2017.07.01.ja03

\section{INTRODUCTION}

Organization justice is important because positive outcomes result from its presence and negative outcomes result from its absence. These outcomes include employee performance, satisfaction, withdrawal (i.e., absenteeism, turnover), counterproductive work behavior (e.g., employee theft), organizational commitment, and organizational citizenship behavior (CohenCharash and Spector, 2001; Colquitt et al., 2001).

Employee perceived organizational fairness or justice perceptions positively affects their attitudes and behaviors. Employees exhibit increased job commitment and Organizational Citizenship Behavior (OCB) (Wat and Shaffer, 2005; Williams, et al., 2002; Colquitt et al., 2001); high job satisfaction (Colquitt et al., 2001); high organizational trust and psychological empowerment (Wat and Shaffer, 2005); high organizational commitment, social behavior, and team loyalty (Murphy et al. 2006); 
increased job performance (Colquitt et al. 2001) and satisfaction with performance appraisal system (Pareke, 2005).

When employees' perception about organizational fairness is negative (i.e. they perceive injustice) their attitudes and behaviors are negatively affected and in that case their OCB tends to be low, increased crimes and intention to protest (Skitka and Bravo, 2005), feel anger and disrespect (Miller, 2001); involve in Organizational misbehavior (OMB), Vardi and Wiener, 1996), counterproductive work behavior (CWB) Spector and Fox (2002); and workplace aggression (Baron and Richardson, 1994).

Perception of organizational injustice is also found to affect employees' health. In a longitudinal research brought about in Finland it was identified that "lack of organizational justice causes decline in subsequent self-rated health status" (Elovainio, Kivimaki, and Vahtera, 2005), "absence due to sickness" (Kivimaki et al. 2007), and "psychiatric disorders" (Kivimaki, Elovainio, Virtanen, and Stansfeld, 2003). Positive or negative effects of injustice are actually the ultimate outcome of the employees' behavioral responses to injustice.

Previous research addressed the effect of distributive and procedural justice on employees' job satisfaction (Fields et al., 2000). Pareke (2005) argued that distributive and procedural justice influence employees' job satisfaction. Samad (2006) concluded that procedural and distributive justice affect job satisfaction. While Martinez-tur et al. (2006) concluded that distributive justice is the main determinant to predict customer satisfaction, followed by procedural, and interactional justice, respectively.

Procedural justice concentrates on the fairness of processes and procedures related to employee in an organization while interactional justice is concerned with the interpersonal dealing; employees receive from their managers during these procedures (Chang, 2005). Originally interactional justice was a third type of justice as described by Bies and Moag (1986). However, following studies identified interactional justice as the "social" side of procedural justice, rather than any different type of justice (e.g., Brockner and Wiesenfeld, 1996; Cropanzano and Greenberg, 1997; Folger 
and Bies, 1989; Tyler and Bies, 1990). Yet some studies have recommended considering interactional justice a distinct form of justice (Malatesta and Byrne, 1997; Masterson, Lewis-McClear, Goldman and Taylor, 1997; Moye, Masterson and Bartol, 1997).

People react not only to outcomes and procedures, but also to interpersonal treatments. It is also clear that there are both structural and social elements that affect justice perceptions (Brockner, Ackerman, and Fairchild, 2001; Cropanzano and Greenberg, 1997; Folger and Skarlicki, 1998; Greenberg, 1993a).

\section{Research Problem}

Organizations like to maintain the environment of fairness in their affairs, (e.g., distribution of rewards, procedures pertaining to the appraisals) but they often fail to make their employees satisfied in this regard. Such unsatisfied employees are likely to develop grievances against their organizations and frequently look for alternative job opportunities. In addition there is an increasing tendency of employees of becoming involved in workplace deviance; organizational or interpersonal. On the other hand student in the universities are found complaining against the education (teaching) and non- education (support) staff of noncooperation and negative behaviours towards students. Therefore it is important to study the perception of employees' about organizational injustice and its relational impact on employees' behaviors.

\section{RESEARCH OBJECTIVES}

The research has two objectives. First, determine the relationship between perceived overall organizational injustice (OOIj) and workplace deviance (WD) among two groups: educators and supporters. Second, this study investigates the relationship between the perceived overall organizational 
injustice (OOIj) and turnover intention among two groups: educators and supporters.

The objectives of the research are to be achieved by focusing on the following questions:

i- What is the effect of perceived overall organizational injustice on work place deviance (WD)?

ii- What is the effect of perceived overall organizational injustice on turnover intention (TI)?

\section{LITERATURE REVIEW}

\section{Organizational Justice/ Injustice}

Nowadays fairness and justice are core issues for managers interested in ensuring equal employment opportunities, fair labor practices and devising performance based compensation. Managers are responsible for fair treatment among employees from all the three dimensions of justice (distributive, procedural and interactional). Differing perspectives, interests and goals of managers and subordinates about fair and just treatment, make the objective complicated and difficult. The multidimensionality of fairness becomes more important when we consider how people disagree about the definition of fairness. The different answers to questions about fairness depend on whether the focus is on outcomes, procedures or motives.

Since the beginning of organizational justice research, scholars were concerned about maintaining fairness in organizational domains such as conflict management, staff selection, employee disputes and wage compromise, etc.

\section{Distributive Justice}

Historically, Adam's (1965, p. 267-299) equity theory addressed justice issue. According to the theory "people balance the ratios of their own 
work outcomes (rewards) to their own work inputs (contributions) and the same ratios of a fellow-worker. If the ratios are not equal, the person whose ratio is higher is thought to be inequitably overpaid, whereas the person whose ratio is lower feels that he was inequitably underpaid"(Adam, 1965). The equity theory pointed out that relatively low reward would produce dissatisfaction which would then motivate individuals to act to reduce the inconsistency between their ratio and that of their coworker. According to equity theory, this difference gives rise to negative emotions and motivates the individual to reduce the imbalance (Cropanzano, 1993). Various studies have been conducted to determine how employees behave when they perceive an injustice. Managers should pay close attention to justice violations in the workplace since these may give rise to employees' negative responses. Injustices, however, can also generate negative consequences that are less direct. Various studies have examined the influence of fair treatment of employees on organizational variables such as job satisfaction (Bateman and Organ, 1983), trust in and loyalty to the leader (Deluga, 1994), organizational citizenship behavior (Morrison, 1994), and employee theft (Greenberg, 1990). The fair treatment among employees increases job satisfaction, develops relationships between supervisors and employees, promotes organizational citizenship behavior, and decreases cases of employee theft, thus indirectly benefiting the organization.

Normally, people use three main justice rules to determine outcome justice: the contributions rule (equity rule), the needs rule, and the equality rule (Leventhal, 1976.). The purpose of outcomes or decisions based on the equity rule is to achieve and increase productivity and a high performance level. The equality rule is used when the goal is to preserve social harmony, while the needs rule is applied when the objective is to foster personal welfare.

\section{Procedural Justice}

Outcomes or decisions (distributive justice) are not the only relevant issue to an individual - the way one is treated is equally important. 
Skarlicki and Latham(1996), defined procedural justice as "the extent to which fair procedures and processes are in place and adhered to and to which individuals see their leaders as being fair and sincere and logical or rational in what they do" (Ivancevich and Matteson, 2002). Folger and Cropanzano (1998:26) define procedural justice as the "fairness issues concerning the methods, mechanisms, and processes used to determine outcomes".

According to Thibaut and Walker (1975), employees evaluate the fairness of procedures using two types of control: the amount of control they have over the procedures used to make a decision (process control) and the amount of control they have to alter the decision (decision control). People like procedures that permit them to feel that they have participated in making a decision that will affect them. Later, research concluded that procedures which allowed employees the opportunities to influence a decision were perceived as fairer than those procedures which ignored process control.

\section{Interactional Justice}

The concept of interactional justice was introduced by Bies and Moag (1986). It is defined as "the quality of interpersonal treatment that people expect to receive when procedures are implemented" and emphasizes "the importance of truthfulness, respect and justification as fairness criteria of interpersonal communication" (Bies, 1987; Bies and Moag, 1986; Tyler and Bies, 1990). Thus, interactional justice deals with the human aspect of organizational practices such as politeness, honesty and respect and, as such is related to the communication aspects between the source and target of justice, (Bies and Moag, 1986; Tyler and Bies, 1990). It has been argued that fairness is not only determined by the formal policies and procedures of the organization but leaders are also considered to be an important source of fairness (Cobb, Vest and Hills, 1997). Many researchers have generally focused on the leaders' treatment

with their subordinates. This "treatment" is exhibited by the content of the message conveyed by the leaders as well as by the conduct of their 
behavior like courtesy, respect (Bies, Shapiro and Cummings, 1988; Cobb, 1992; Tyler, Lind et al., 1998), or the way of implementing the policies and procedures (Bies, Martin and Brockner, 1993; Cobb and Frey, 1996; Tyler and Bies, 1990).

Interactional Justice is one of the most important considerations in an organization due to its impact on an individual's feelings, perceptions and consequent behavior. For example, interactional fairness is considered to improve employees' attitude and conduct towards the source of a particular treatment (Bies and Moag, 1986; Colquitt et al., 2001). Moreover, research has proved a positive relationship between interpersonal justice and employees' level of trust and collective esteem of the group experiencing the treatment or interaction (Colquitt, 2001).

Normally, although organizations make efforts to display fair conduct, employees will perceive some types of interpersonal treatment to be unfair and other types of treatment to be fair (Folger and Cropanzano, 1998). That is why it has been observed that the interpersonal sensitivity component of interactional injustice is associated with the quality of the interpersonal treatment an employee receives within an organization (Colquitt et al., 2001; Folger and Cropanzano, 1998; Folger and Konovsky, 1989). It has also been stated that interpersonal treatment is related to varied emotions that individuals feel towards agents or authority figures in response to their decision making within an organizational structure (Tyler, 1989).

\section{Overall Justice/Injustice}

Despite the fact that there is a considerable amount of research that focuses on three dimensions of justice perceptions, there is evidence that recent research shifted its emphasis on the examination of overall justice judgments (Tomblom and Vrmunt, 1999: Lind, 2001a, b: Ambrose and Arnaud, 2005). One of the reasons is that different types of justice may not accurately express individuals' justice experience (Ambrose and Schminke, 2009). Research has suggested that when individuals look at 
justice they make a holistic judgment about justice (Greenberg, 2001), while Shapiro argued that individuals are more concerned about their general experience of injustice than types of injustice (Shapiro, 2001). Moreover it has been suggested that a simple approach to justice may be more valid than those focusing on different types of justice (Flinder, 2001). In present research this simple approach to overall injustice was adopted.

In most of the researches the term justice has been used for explaining the fairness at workplace, but some researchers have suggested that it is more appropriate that we should consider the psychology of injustice. This shift in the terminology is due to the fact that the organizational justice construct is discussed heavily from the situation of injustice rather justice (Bies, 2001) and individuals feel more strongly affected by unfair incidents than fair incidents (Folger and Cropanzano, 1998; Judge and Colquitt, 2004). Therefore, instead of discussing justice, it would be more appropriate to discuss injustice because this will make a more logical sense for the readers (Ambrose and Schminke, 2009). Hence in this study overall injustice would be studied in relation to the workplace deviance (WD) and turnover intention (TI).

\section{Employees' Responses and Reactions to Injustice}

When employees face injustice, it is a bitter experience for them and damaging for individuals as well as for organizations. Very few get benefit from an environment of unfairness and injustice but most of the employees bear harm in such situations. So, organizations should reduce injustice by studying employees' responses to injustices and prepare written guidelines, procedures and policies to make decisions and engender fairness.

According to Sheppard et al (1992), employees generally deal with injustices in one of four ways. Firstly, they live with the injustice and continue as if nothing has happened. Secondly, they can change their behavior to remove the injustice - for example; they can work less hard if their efforts are not equitably rewarded. Thirdly, they can rationalize 
the injustice by renaming, removing or redefining it. Lastly, employees can decide to resign or request a transfer in order to avoid confronting continued injustice. It is important to discuss employees' behavior when they experience injustice and to provide guidelines for what organizations can do to improve the perceived fairness of practices.

\section{Counter Productive Work Behavior, Workplace Sabotage and Workplace Deviance}

Organizational theorists have concluded that organizations cannot afford to hire employees involved in counterproductive work behavior (CWB) like aggression, interpersonal conflict, theft, sabotage etc. (Fox Spector et. al. 2001). Researchers have pointed out that counterproductive work behaviors (CWB) are emotion-based responses (over acts, disobeying instructions or a deliberate error in doing work, anti-social behavior, delinquency, revenge, mobbing/bullying and deviance) to adverse and stressful environments of the organizations (Fox and Spector, 1999).

Workplace sabotage (WPS) is a behavior that "damages, disrupts, or subverts the organization's operations for the personal purposes of the saboteur by creating unfavorable publicity, embarrassment, delays in production, damage to property, the destruction of working relationships, or the harming of employees or customers" (Crino, 1994, p. 312). Recent research conceptualizes sabotage as a rational behavior that emerges from one's reaction to one's surroundings (Analoui, 1995; DiBattista, 1996; Jermier, 1988). In literature workplace sabotage (WPS) and work deviance (WD) are used with overlapping definitions, yet WPS is broader category of WD (Ambrose et al., 2002). In this research we will consider WD as a limited concept of WPS.

When employees' behavior significantly violates a company's norms, policies, or rules and endangers the well-being of the organization and/or its members, such behavior is termed as work deviant behavior or work deviance (Robinson and Bennett, 1995). WPD is an intended desire to harm an organization (Omar et al. 2011). A study conducted on sample of 
nurses in Pakistani culture revealed negative behaviors of mistreatment with nurses in hospitals (Somani and Khowaja, 2012). It has also been concluded that mistreatment at workplace results in negative outcomes (Laschinger et al., 2014).

Employees normally retaliate against abusive supervisor in a deviant manner (Tepper et al., 2009). Workplace deviant behavior includes both behaviors targeted at organizations (e.g., theft, coming to work late, putting little effort into work) and individuals in the workplace, such as supervisors or coworkers (e.g., making fun of others, playing mean pranks, acting rudely, arguing).

In this limited sense WD has two perspectives: organizational deviance (OD) and interpersonal deviance (ID). The former refers to a situationbased perspective caused by an unpleasant work environment, while the latter is person-based and depends upon the personality and the tendency of individuals behaving in such disappointing situations irrespective of the nature of the situation.

\section{Turnover Intention}

Unfair treatment in the organization has also been frequently linked to increased intention to leave the organization ( $\mathrm{Li}$ and Cropanzano, 2009; Cole et al. 2010). Turnover intention is, "the extent to which an employee plans to quit the organization, reflect an alternative form of withdrawal and is the strongest predictor of actual turnover" (Podsakoff et al. 2007). Obviously, a fair treatment in the organization informs the employee that the organization values them as an important member of the organization (Lind and Tyler, 1988), while unfair treatment may be an indication of disrespect for the employee, who will decide not to stay further in this organization.

\section{Theoretical Support and Hypothesis}

According to the social exchange theory and $\mathrm{OCB}$, an individual who perceives the reciprocity between contributions and benefits as fair, 
will try to strengthen the relationship by acting with a pro-social or constructive behavior: with a voice or loyal behavioral response. If the individual experiences the relationship as unfair, an anti-social or destructive behavior is adopted (e.g., exit, neglect, or increasing turnover intentions and work deviance).

According to the Cognitive Appraisal Model (Lazarus and Folkman, 1984) people respond to an event by mentally imagining the impact on them, and the event causes stress only if it is cognitively appraised as a stressor. This cognitive appraisal process will happen, according to Lazarus and Folkman (1984), in two different stages: one primary appraisal when the individual considers the extent to which he or she could be harmed by the event, and a second appraisal when he or she considers different coping strategies to avoid or minimize harm. Organizational injustice could constitute a feeling of interactional unfairness according to the cognitive appraisal model (Greenberg, 2004).

Reactive content theories focus on how individuals respond to unfair decisions, situations or relationships. These theories explain that people react to unfair relations by exhibiting certain negative emotions such as resentment, anger, dissatisfaction, disappointment and unhappiness (Folger, 1984). In an attempt to redress the experienced inequity, employees will seek restitution, engage in retaliatory behavior or restore psychological equity by justifying the injustice or leaving the organization. While justifying his retaliatory behavior the employee may become involved in work deviance otherwise intend to change the organization.

\section{Research Hypothesis}

H1: Perception of overall Organizational Injustice (OOIj) is positively and significantly correlated to Work Deviance (WD).

H1a: Perception of overall Organizational Injustice (OOIj) is positively and significantly correlated to Organizational Deviance (OD). 
H1b: Perception of overall Organizational Injustice (OOIj) is positively and significantly correlated to Interpersonal Deviance (ID).

H2 Perception of overall Organizational Injustice (OOIj) is positively and significantly correlated to Turnover Intention (TI).

\section{Methodology}

The present research is quantitative and empirical in nature and focuses on the relationship between perception of overall injustice, work deviance, and turnover intention. The hypotheses of the study were tested through the collection of quantitative data obtained with the use of a questionnaire from the relevant respondents to ascertain any causal relationships. This was a cross sectional field study using survey strategy. The population of the research comprised of the employees of higher education institutions. The participants belonged to the four different universities of Rawalpindi and Islamabad regions of Pakistan.

Stratified quota sampling was used and the respondents were classified into two strata, educators-employees engaged in teaching (lecturers, Assistant Professors, Professors) and supporters-engaged in other administrative and office assignments (Clerical staff, Assistant Directors, Deputy Directors, Directors etc.) The respondents constituted a convenient sample. Data was collected through self-administration of questionnaires by the investigator or his representative.

\section{Instruments and Measures}

Overall organizational injustice: Employee perceptions of injustice were measured through six-item scale developed and validated by Ambrose and Schminke (2009), with a slight modification. The OOIj scale consists of three items to measure individuals' personal injustice experiences: "Overall, I'm treated unfairly by my organization" (OOIj1); "In general, 
I can count on this organization to be unfair" (OOIj2); "In general, the treatment I receive around here is unfair" (OOIj3).

The OOIj also includes three items to measure the fairness of the organization: "Usually, the way things work in this organization are not fair" (OOIj4); "For the most part, this organization treats its employees unfairly" (OOIj5); "Most of the people who work here would say they are often treated unfairly" (OOIj6).

Individuals responded their agreement with each OOIj statement (as well as those for work deviance and turnover intentions below) on a 7point scale between 1 (strongly disagree) and 7 (strongly agree). Responses to the items were recorded to parallel the specific injustice items, such that higher ratings reflect greater perceptions of unfairness. The $\alpha$ for overall injustice was .91

Organizational deviance: OD (Organizational deviance) of employee was measured though a 9-item $(\alpha=.94)$ organizational deviance scale (Bennett and Robinson, 2000). Turnover intention (TI) was assessed using a 5-item scale adapted from Hom and Griffeth (1995). Responses to all items were made on a 7-point Likert scale between (1) "Strongly Disagree" and (7) "Strongly Agree"

\section{Data Analysis}

Three hundred questionnaires were distributed among teaching and non -teaching staff of the three universities of Islamabad, out of which 235 responded, representing $78 \%$ response rate. As Table 1 reports, $66 \%$ were male and 44\% were female, $140(60 \%)$ were educators and 95(40\%) were supporting staff. The demographic details tell that majority of the respondents were male 156 (66\%) married 173 (70\%), having high qualification-above master degree 228(97\%) and having job experience of more than 5 years 153 (65\%). Demographic variables are kept as control variables. Data was analyzed using SPSS version 22. 


\section{Confirmatory Factor Analysis of the Study Variables}

For the confirmation of a pre-specified relationship and for evaluating the distinctiveness of all the measures, a confirmatory factor analysis (CFA) using covariance matrix was undertaken. 17 items were used to identify the respondents' responses. Six items were used to measure the perception of overall organizational injustice (OOIj). Five items were used to measure organizational deviance (OD), four items for measuring interpersonal deviance (ID) and two items for turnover intention (TI).

\section{Construct and instrument reliability}

The reliability of the construct was measured by computing the Cronbach's alpha values.

As Table 2 shows, the reliability of overall organizational injustice is .87 , and for dependent variables organizational deviance, interpersonal deviance, and turnover intention, it is $.79, .81$ and .76 respectively, representing acceptable internal consistency of the study variables. The value of comparative fit index (CFI) is higher than .90. This indicates the strong evidence of unidimensionality. Further, NFI (Normed Fit Index) values range between .90 and 1.00. This is the indication of convergent validity. All the CFI and NFI values for educators and supporters are given in Table 2.

\section{Descriptive Statistics and Correlation}

The descriptive statistics and the correlation among the study variables (predictor and criterion variable) are shown in Table 3. Educators' perceptions of overall organizational injustice were relatively high; $(M=5.88, S D=1.05)$. It was $(M=5.63, S D=.87)$ for organizational deviance, $(\mathrm{M}=5.29, \mathrm{SD}=.77)$ for interpersonal deviance and collectively $(\mathrm{M}=5.83$, $\mathrm{SD}=1.05)$ for work deviance. The level of turnover intentions experienced by the respondents was relatively high $(\mathrm{M}=5.91, \mathrm{SD}=1.02)$.

All study variables were found to be significantly inter-correlated. Correlations among overall organizational injustice and dependent 
variables were significantly high, ranging from $\mathrm{r}=.48(\mathrm{p}<0.01)$ to $\mathrm{r}=.83$ $(p<0.01)$. Accordingly, the correlations between overall organizational injustice and organizational deviance, interpersonal deviance, work deviance were $(\mathrm{r}=.52, \mathrm{p}<0.01),(\mathrm{r}=.52, \mathrm{p}<0.01),(\mathrm{r}=.83, \mathrm{p}<0.01,(\mathrm{r}$ $=.74, \mathrm{p}<0.01)$, and $(\mathrm{r}=.63, \mathrm{p}<0.01)$ respectively.

The perceptions of non-teaching staff/supporters for overall organizational injustice was also high; $(M=5.96, S D=0.99)$. It was $(M=5.52$, $\mathrm{SD}=.92)$ for organizational deviance, $(\mathrm{M}=5.46, \mathrm{SD}=.92)$ for interpersonal deviance and collectively $(\mathrm{M}=5.92, \mathrm{SD}=1.02)$ for work deviance. The level of turnover intentions experienced by nonteaching staff were relatively low $(\mathrm{M}=5.29, \mathrm{SD}=0.98)$.

All study variables were found to be significantly inter-correlated. Correlations among overall organizational injustice and dependent variables were significantly high, ranging from $r=.63(\mathrm{p}<0.01)$ to $r$ $=.83(\mathrm{p}<0.01)$.

\section{Hypothesis Testing}

Before hypotheses testing two sample were identified different on the basis of $t$-test using SPSS. Hierarchical regression was conducted to measure the relationship between perceived overall organizational injustice work deviance and turnover intention, separately for both types of respondents, educators and non-educator staff. Demographic variables (age, gender, marital status, education level and organizational tenure) were considered controlled variables Table 4 shows that overall educator organizational injustice was found to explain $48 \%\left(\mathrm{R}^{2}=.48, \mathrm{p}<0.01\right)$ of the observed variations in organizational deviance, $38 \%$ to explain interpersonal deviance $\left(\mathrm{R}^{2}=.38, \mathrm{p}<0.01\right), 40 \%$ of work deviance $\left(\mathrm{R}^{2}=.40\right.$, $\mathrm{p}<0.01)$ and $68 \%$ of turnover intention $\left(\mathrm{R}^{2}=.68, \mathrm{p}<0.01\right)$. While for nonteaching staff (supporters), overall organizational injustice was found to explain $52 \%\left(\mathrm{R}^{2}=.52, \mathrm{p}<0.01\right)$ of the observed variations in organizational deviance, $48 \%$ to explain interpersonal deviance $\left(\mathrm{R}^{2}=.48, \mathrm{p}<0.01\right), 66 \%$ 
of work deviance $\left(\mathrm{R}^{2}=.66, \mathrm{p}<0.01\right)$ and $36 \%$ of turnover intention $\left(\mathrm{R}^{2}\right.$ $=.36, \mathrm{p}<0.01)$. In the light of the above results it is concluded that $\mathrm{H} 1$, $\mathrm{H} 1 \mathrm{a}, \mathrm{H} 1 \mathrm{~b}$ and $\mathrm{H} 2$ are supported.

\section{Discussion}

It was found that perception of overall organizational injustice has a significant positive influence on work deviance and turnover intentions. This result is consistent with the previous studies (Appelbaum, Laconi and Matousek, 2007; Browning, 2009; Omar, Halim, Zainah, Farhadi, Nasir and Kairudin, 2011.)

An interesting finding of the present study is that, educators are less responsive towards work deviance (.48) which is relatively less than the same response of supporters (.58). But on the other hand their turnover intention (.58) is higher than the turnover intention of the supporters (.42). It is also obvious that educators' turnover intention (.58) is greater than their work deviance (.48) while it is opposite in the case of supporters where supporters work deviance (.58) is greater than their turnover intention (.42) as indicated in Figure2.

These results may be interpreted on the basis of nature of the job and opportunities of alternative jobs. The job nature of the educators requires a high level of commitment and courtesy therefore despite the perception of overall organizational injustice; educators' response is low towards workplace deviance while in situations of injustice their turnover intention is relatively higher than that of the supporters, as many good alternative teaching opportunities are available for university teachers and they do not normally keep sticking to one institution for long.

On the other hand non-teaching staff is connected to public dealing so they involve in workplace deviance more frequently than the educators, while due to non-availability of alternative jobs, their turnover intention is relatively low. 


\section{Strengths of the Study}

The present research used a measure of overall organization injustice directly keeping in view the psychology of injustice (De Cremer \& Ruiter, 2003) because people are normally affected more by unfair event than by fair events (Folger, 1984; Folger \& Cropanzano, 1998; Judge \& Colquitt, 2004), while most of the previous studies used term justice for discussing fairness.

Second, this study has been conducted in a culture of high power distance with risk averter population in a developing country like Pakistan- a different contextual perspective.

\section{Conclusion}

Previous research has established a negative relationship between three dimensions of organizational justice (distributive, procedural and interactional), workplace deviance and turnover intentions, and some research concluded that in this relationship perception of overall injustice mediates the relationships. However this study has validated the construct of overall injustice and established a direct relationship between workplace deviance and turnover intention using two types of samples. The study based on a small size of the sample and may have common method bias. Further research may use large sample size and further validate the overall injustice construct and considering removal of $\mathrm{CMB}$ if found.

\section{REFERENCES}

Adams, J. S. (1965). Inequity in social exchange. In L. Berkowitz (Ed.), Advances in Experimental Social Psychology, 2, 267-299). New York: Academic Press.

Alexander, S., \& Ruderman, M. (1987). The role of procedural and distributive justice in organizational behavior. Social fustice Research, 1, 177-198. http://dx.doi.org/10.1007/BF01048015 
Allyn \& Bacon. Aquino, K., Griffeth, R. W., Allen, D. G., \& Hom, P. W. (1997). Integrating justice constructs into the turnover process: A test of a referent cognition model. Academy of Management fournal, 40, 1208-1227.http://dx.doi.org/10.2307/256933

Ambrose, M. L., Seabright, M. A., \& Schminke, M. (2002). Sabotage in the work-place: The role of organizational justice. Organizational Behavior and Human Decision Processes, 89, 947-965 http://dx.doi.org/10.1016/ S0749-5978(02)00037-7

Ambrose, M. L, \& Arnaud, A. (2005). Distributive and procedural justice: Construct distinctiveness; construct interdependence, and overall justice. In J. Greenberg \& J. Colquitt (Eds.). The Handbook of Organizational fustice, 59-84. Lawrence Erlbaum Associates, Mawheh: New Jersey.

Appelbaum, S.H., Laconi, G.D., \& Matousek, A. (2007). Positive and negative deviant workplace behaviours: Causes, impacts and solutions. Corporate Governance, 7(5), 586-598. http://dx.doi.org/10.1108/147207 00710827176.http://dx.doi.org/10.1108/14720700710827176

Baron, R.M., \& Kenny, D.A. (1986). The moderator-mediator variable distinction in social psychological research: Conceptual, strategic, and statistical considerations. Journal of Personality \& Social Psychology, 51, 1173-1182.http://dx.doi.org/10.1037/0022-3514.51.6.1173

Barling, J., \& Phillips, M. (1993). Interactional, formal, and distributive justice in the workplace: An exploratory study. Fournal of Psychology: Interdisciplinary and Applied, 127, 649-656. http:// dx.doi.org/10.1080/00223980.1993.9914904

Baron, R. M., \& Kenny, D. A. (1986). The moderator-mediator variable distinction in social psychological research: Conceptual, strategic, and statistical considerations. Journal of Personality \& Social Psychology, 51, 1173-1182.http://dx.doi.org/10.1037/0022-3514.51.6.1173

Bies, RJ. (2001). Interactional (in) justice: The sacred and the profane. In J. Greenberg \& R Cropanzano (Eds.), Advances in Organizational fustice. Stanford, CA: Stanford University Press.

Bies, R. J., \& Moag, J. F. (1986). Interactional justice: Communication criteria of fairness. In R. L. Lewicki, B. H. Sheppard, \& R. J. Bies (Eds.), 
Research on Negotiations in Organizations, 1, 43-55). Greenwich, CT: JAI Press.

Bobocel, D. R., \& Holmvall, C. 2001. Are interactional justice and procedural justice different? Framing the debate. In S. Gilliland, D. Steiner, \& D. Skarlicki (Eds.), Research in Social Issues in Management: Theoretical and Cultural Perspectives on Organizational fustice, 85-110. Greenwich, CT: Information Age Publishing.

Byrne, Z. S., \& Cropanzano, R. (2001). The history of organizational justice: The founders speak. In R. Cropanzano (Ed.), Justice in Workplace: From Theory to Practice, 2. Mahwah, NJ: Lawrence Erlbaum Associates.

Cohen-Charash, Y., \& Spector, P. E. (2001). The role of justice in organizations: A meta-analysis. Organizational Behavior and Human Decision Processes, 86, 278-321. http://dx.doi.org/10.1006/ obhd.2001.2958

Cohen, R. L., \& Greenberg, J. (1982). The justice concept in social psychology. In J. Greenberg \& R. L. Cohen (Eds.), Equity and Justice in Social Behavior. New York: Academic.

Cohen, S., Kamarck, T., \& Mermelstein, R. (1983). A global measure of perceived stress. Journal of Health and Social Behavior, 24, 385-396. http://dx.doi.org/10.2307/2136404

Colquitt, J. A. 2001. On the dimensionality of organizational justice: A construct validation of a measure. Fournal of Applied Psychology, 86, 386-400. http://dx.doi.org/10.1037/0021-9010.86.3.386 PMid:11419799

Colquitt, J. A., Conlon, D. E., Wesson, M. J., Porter, C. O., \& Ng., K. Y. (2001). Justice at the millennium: A meta-analytic review of 25 years of organizational justice research. Fournal of Applied Psychology, 86, 425-445. http://dx.doi.org/10.1037/0021-9010.86.3.425 PMid:11419803

Colquitt, J. A., \& Shaw, J. C. 2005. How should organizational justice be measured? In J. Greenberg and J. A. Colquitt (Eds.). The Handbook of Organizational fustice, 113-152. Mahwah, NJ: Erlbaum. 
Colquitt, J. A., \& Greenberg, J. (2003). Organizational justice: A fair assessment of the state of the literature. In J. Greenberg (Ed.), Organizational behavior, $\left.2^{\text {nd }} \mathrm{Ed}\right), 165-210$ ).

Colquitt, J. A., Greenberg, J., \& Scott, B. A. (2005) Organizational justice: Where do we stand? In J. Greenberg \& J. A. Colquitt (Eds.), Handbook of Organizational Fustice, 589-619. Mahwah, NJ: Lawrence Erlbaum Associates.

Colquitt, J. A., Greenberg, J., \& Zapata-Phelan, C. P. (2005). What is organizational justice? A historical overview. In J. Greenberg \& J. A. Colquitt (Eds.), Handbook of Organizational Justice, 3-56. Mahwah, NJ: Lawrence Erlbaum Associates.

Cropanzano, R., \& Ambrose, M. L. 2001. Procedural and distributive justice is more similar than you think: A monistic perspective and a research agenda. In J. Greenberg \& R. Cropanzano (Eds.), Advances in Organizational fustice, 119-151. Stanford, CA: Stanford University Press.

Cropanzano, R., Byrne, Z. S., Bobocel, D. R., \& Rupp, D. R. (2001). Moral virtues, fairness heuristics, social entities, and other denizens of organizational justice. Fournal of Vocational Behavior, 58, 164-209. http://dx.doi.org/10.1006/jvbe.2001.1791

Cropanzano, R., Prehar, C. A., \& Chen, P. Y. (2002). Using social exchange theory to distinguish procedural from interactional justice. Group \& Organization Management, 27, 324- 351. http:// dx.doi.org/10.1177/1059601102027003002

Cropanzano, R., \& Greenberg, J. (1997). Progress in organizational justice: Tunneling through the maze. In C. Copper \& I. Robertson (Eds.), International Review of Industrial and Organizational Psychology, 317-372.

Elovainio, M., Kivimäki, M., \& Vahtera, J. (2002). Organizational Justice: Evidence of a New Psychosocial Predictor of Health. American fournal of Public Health, 92, 105-108. http://dx.doi.org/10.2105/ AJPH.92.1.105 PMid:11772771 PMCid:PMC1447369 
Fairbrother, K., \& Warn, J. (2003). Workplace dimensions, stress and job satisfaction. Fournal of Managerial Psychology, 18, 8-21. http:// dx.doi.org/10.1108/02683940310459565

Folger, R., \& Cropanzano, R. (2001). Fairness theory: Justice as accountability. In J. Greenberg \& R. Cropanzano (Eds.), Advances in Organizational fustice, 89- 118.

Folger, R \& Greenberg, J. (1985). Procedural justice: an interpretative analysis of personnel systems. Research in Personnel and Human Resource Management, 3,141-183.

Folger, R \& Konovsky, MA. (1989). Effects of procedural and distributive justice on reactions to pay raise decisions. Academy of Management fournal, 32(1), 115-130. http://dx.doi.org/10.2307/256422

Folger, R \& Skarlicki, D. (1999). Unfairness and resistance to change: hardship as mistreatment. Fournal of Organizational Change Management, 12(1), 35-50. http:// dx.doi.org/10.1108/09534819910255306

Folger, R. (1977). Distributive and procedural justice: Combined impact of "voice" and improvement on experienced inequity. Journal of Personality and Social Psychology, 35, 108- 119. http:// dx.doi.org/10.1037/0022-3514.35.2.108

Folger, R., \& Konovsky, M. A. (1989). Effects of procedural and distributive justice on reactions to pay raise decisions. Academy of Management fournal, 32, 115-130. http://dx.doi.org/10.2307/256422

Friedman, T.L. (2005). The world is flat. New York: Farrar, Straus, and Giroux.

Gilliland, SW. 1993. The perceived fairness of selection systems: an organizational justice perspective. Academy of Management Review, 18, 694-734. http://dx.doi.org/10.2307/258595 http://dx.doi.org/10.5465/ AMR.1993.9402210155

Greenberg, J. (2001a). Setting the justice agenda: Seven unanswered questions about "what, why, and how." Journal of Vocational Behavior, 58, 210-219. http://dx.doi.org/10.1006/jvbe.2001.1792 
Greenberg, J. 2001b. The seven loose cannons of organizational justice. In J. Greenberg \& R. Cropanzano (Eds.), Advances in Organizational Fustice, 245-271.

Greenberg, J. (1987). A taxonomy of organizational justice theories. Academy of Management Review, 12, 9-22. http://dx.doi.org/10.5465/ AMR.1987.4306437 http://dx.doi.org/10.2307/257990

Greenberg, J. (1988). Equity and workplace status: A field experiment. Journal of Applied Psychology, 73, 606-613. http:// dx.doi.org/10.1037/0021-9010.73.4.606

Greenberg, J. (1990). Organizational justice: yesterday, today, and tomorrow. Fournal of Management, 16, 2, 399-432. http:// dx.doi.org/10.1177/014920639001600208

Greenberg, J. (1987). A taxonomy of organizational justice theories. Academy of Management Review, 12, 9-22. http://dx.doi.org/10.5465/ AMR.1987.4306437 http://dx.doi.org/10.2307/257990

Greenberg, J. (1990). Employee theft as a reaction to underpayment inequity: The hidden cost of pay cuts. Journal of Applied Psychology, 75, 561-568. http://dx.doi.org/10.1037/0021-9010.75.6.667 http:// dx.doi.org/10.1037/0021-9010.75.5.561

Greenberg, J. (1993). The social side of fairness: Interpersonal and informational classes of organizational justice. In R. Cropanzano (Ed.), Justice in the Workplace: Approaching Fairness in Human Resource Management. Hillsdale, NJ: Lawrence Erlbaum Associates.

Greenberg, J. (1997). A social influence model of employee theft: Beyond the fraud triangle. In R. J. Lewicki, R. J. Beis \& B. H. Sheppards (Eds.), Research on Negotiation in Organizations, 6, 29-52). Greenwich, CT: JAI Press.

Greenberg, J. (2004). Stress fairness to fare no stress: Managing workplace stress by promoting organizational justice. Organizational Dynamics, 33, 4, 352-365. http://dx.doi.org/10.1016/j.orgdyn.2004.09.003

Greenberg, J., \& Lind, E. A. (2000). The pursuit of organizational justice: From conceptualization to implication to application. In C. L. Cooper \& E. A. Locke (Eds.), I/O Psychology: What We Know about Theory and Practice, 72-105). Oxford, England: Blackwell. 
Greenberg, J., \& Folger, R. (1983). Procedural justice, participation, and the fair process effect in groups and organizations. In P. B. Paulus (Ed.), Basic Group Processes, 235-256). New York: Springer-Versa.

Henle, C. A. (2005). Predicting workplace deviance from the interaction between organizational justice and personality. fournal of Managerial Issues, 17, 247-263.

Henle, C. A. (2005). Predicting workplace deviance from the interaction between organizational justice and personality. fournal of Managerial Issues, 17, 247-263.

Herzberg, F. (2003). One more time: How do you motivate employees? Harvard Business Review, 81, 87-96. PMid:12545925

Hauenstein, N. M. T., McGonigle, T., \& Flinder, S.W. (2001). A metaanalysis of the relationship between procedural justice and distributive justice: Implications for justice research. Employee Responsibilities and Rights fournal, 13, 39-56.http://dx.doi.org/10.1023/A:1014482124497

Janssen, O. (2004). How fairness perceptions make innovative behavior more or less stressful. Fournal of Organizational Behavior, 25, 201-215 http://dx.doi.org/10.1002/job.238

Judge, T. A., \& Colquitt, J. A. (2004). Organizational justice and stress: The mediating role of work-family conflict. Journal of Applied Psychology, 80(3), 395-404. http:// dx.doi.org/10.1037/0021-9010.89.3.395 PMid:15161400

Kivimäki, M., Elovainio, M., Vahtera, J., Virtanen, M., \& Stansfeld, S.A. (2003). Association between organizational inequity and incidence of psychiatric disorders in female employees. Psychological Medicine, 33, 319-326.http://dx.doi.org/10.1017/S0033291702006591 PMid:12622310

Kivimäki, M., Ferrie, J.E., Brunner, E., Head, J., Shipley, M.J., Vahtera, J., et al. (2005).Justice at Work and Reduced Risk of Coronary Heart Disease Among Employees. Archives of Internal Medicine, 165, 2245-2251.http:// dx.doi.org/10.1001/archinte.165.19.2245 PMid:16246990

Kivimäki, M., Vahtera, J., Elovainio, M., Virtanen, M., \& Siegrist, J. (2007). Effort reward imbalance, procedural injustice and relational injustice as psychosocial predictors of health: complementary or redundant models? Occupational and Environmental Medicine, 64, 
659-665 http://dx.doi.org/10.1136/oem.2006.031310 PMid:17259167 PMCid:PMC2078405

Konovsky, M. 2000. Understanding procedural justice and its impact on business organizations. Fournal of Management, 26, 489-511. http:// dx.doi.org/10.1177/014920630002600306

Konovsky, M. A., \& Cropanzano, R. (1991). Perceived fairness of employee drug testing as a predictor of employee attitudes and job performance. Journal of Applied Psychology, 76, 698-707. http:// dx.doi.org/10.1037/0021-9010.76.5.698 PM id: 1960142.

Laschinger, H. K., Duffield, C., \& Read, E. (2014). Laschinger, H. K. S., Duffield, C. \& Read, E. (2014). The Role of leadership in creating empowering . Australia: Elsevier

Lemons, MA \& Jones, CA. (2001). Procedural justice in promotion decisions: using perceptions of fairness to build employee commitment. Fournal of Managerial Psychology, 16, 268-281. http:// dx.doi.org/10.1108/02683940110391517

Leventhal, G. S. (1976). Fairness in social relationships. In J. W. Thibault, J. T. Spence \& R. C. Carson (Eds.), Contemporary Topics in Social Psychology, 211-239. Morristown, NJ: General Learning Press.

Leventhal, G. S., (1980). What should be done with equity theory? In K. J. Gergen, M. S. Greenberg, \& R. H. Willis (Eds.) Social Exchange: Advances in Theory and Research, 27-55. New York: Plenum.

Lind, E. A., \& Tyler, T. R. (1988). The social psychology of procedural justice. New York: Plenum Press. http://dx.doi.org/10.1007/978-1-4899-2115-4

Lind, E. A., Kulick, C. T., Ambrose, M., \& de Vera Park, M. V. (1993). Individual and corporate dispute resolution: Using procedural fairness as a decision heuristic. Administrative Science Quarterly, 38, 224-251. http://dx.doi.org/10.2307/2393412

Lind, E. A., \& Van den Bos, K. (2002). When fairness works: Toward a general theory of uncertainty management. In B. W. Staw \& R. M. Kramer (Eds.), Research in Organizational Behavior, 24, 181-223). Boston: Elsevier.

Lind, E. A. 2001a. Fairness Heuristic Theory: justice judgments as pivotal cognitions in organizational relations. In J. Greenberg, \& R. Cropan- 
zano (Eds.), Advances in Organizational fustice, 56-88. CA: Stanford University Press.

Lind, E. A. 2001b. Thinking critically about justice judgments. fournal of Vocational Behavior, 58, 220-226. http://dx.doi.org/10.1006/ jvbe.2001.1793

McFarlin, D. B., \& Sweeney, P. D. (1992). Distributive and procedural justice as predictors of satisfaction with personal and organizational outcomes. Academy of Management fournal, 35, , 626-637. http:// dx.doi.org/10.2307/256489

Miller Dale T. Disrespect and the Experience of Injustice. Annual Review of Psychology, 52, 527-553. (doi:10.1146/annurev.psych.52.1.527)

Moorman, R. H. (1991). Relationship between organizational justice and organizational citizenship behaviors: Do fairness perceptions influence employee citizenship? Journal of Applied Psychology, 76, 845-855. http://dx.doi.org/10.1037/0021-9010.76.6.845

Moorman, R. H., Blakely, G. L., \& Niehoff, B. P. (1998). Does perceived organizational support mediate the relationship between procedural justice and organizational citizenship behavior? Academy of Management fournal, 41(3), 351-357. http://dx.doi.org/10.2307/256913

Pareke, F. (2005). Employee perception of justice in the performance appraisal process: evidence from small business in DI Jogjakarta Province, Indonesia. Management fournal, 10(2), 68-84.

Preacher, K.J., \& Hayes, A.F. (2004). SPSS and SAS procedures for estimating indirect effects in simple mediation models. Behavior Research Methods, Instruments, \& Computers, 36(4), 717-731. http:// dx.doi.org/10.3758/BF03206553

Shapiro, D. (2001). The death of justice theory is likely if theorists neglect the "wheels" already invented and the voices of the injustice victims. fournal of Vocational Behavior, 58, 235-242. http://dx.doi.org/10.1006/ jvbe.2001.1795

Somani, R. K., \& Khowaja, K. (2012). Workplace violence towards nurses: A reality from the Pakistani Context. Journal of Nursing Education and Practice, 148-153. 
Taylor, M. (2001). Reflections on Fairness: Continuing the Progression of Justice Research and Practice. Journal of Vocational Behavior, 58, 243-253. http://dx.doi.org/10.1006/jvbe.2001.1796

Tepper, B. J. (2001). Health consequences of organizational injustice: Test of main and interactive effects. Organizational Behavior and Human Decision Processes, 86, 197-21. http://dx.doi.org/10.1006/obhd.2001.2951

Tepper, B. J., Carr, J. C., Breaux, D. M., Geider, S., Hu, C., \& Hua, W. (2009). Abusive supervision, intentions to quit, and employees' workplace deviance: A power/dependence analysis. Organizational Behavior and Human Decision Processes, 109, 156-167. http://dx.doi.org/10.1016/ j.obhdp.2009.03.004

Thibault, J., \& Walker, L. (1975). Procedural justice: A psychological analysis. Hillsdale, NJ: Lawrence Erlbaum Associates.

Tornblom, K. Y., \& Vermunt, R. (1999). An integrative perspective on social justice: Distributive and procedural fairness evaluations of positive and negative outcome allocations. Social fustice Research, 12: 39-64.http://dx.doi.org/10.1023/A:1023226307252

Tyler, T. R., \& Blader, S. L. (2000). Cooperation in groups: Procedural justice, social identity, and behavior engagement. Philadelphia: Psychology Press.

\section{Citation Information}

Rizvi, Syed T., Barry A. Friedman, and Rauf I. Azam. "Overall Injustice, Workplace Deviance and Turnover Intention Among Educators and Supporters." The BRC Academy fournal of Business 7, no. 1 (2017): 45-71. http://dx.doi.org/10.15239/j.brcacadjb.2017.07.01.ja03

\section{Web Appendix}

A web appendix for this paper is available at:

http://dx.doi.org/10.15239/j.brcacadjb.2017.07.01.wa03 